\title{
CHARACTER EDUCATION IN ONLINE LEARNING DURING THE COVID-19 PANDEMIC
}

\author{
Ruly Nadian Sari, Wiwin Windayanti, \\ Maya Aulia \\ Sekolah Tinggi Ilmu Tarbiyah (STIT) \\ Pringsewu
}

Alamat : Jalan Raya Wonokriyo Gadingrejo Pringsewu 35373, Telp. 0729-333091

Email: rulynadiansari@gmail.com, stitpringsewu@gmail.com, mayaaulia30@yahoo.com

\begin{abstract}
Strengthening character education plays an important role in shaping the character of students. A great nation is a nation that has a strong human resource character side by side with superior competence. Character education is a process of applying moral and religious values to students through science, the application of these values to oneself, family, fellow friends, educators and the surrounding environment as well as God Almighty. The presence of the media in the world of education, especially in the context of teaching effectiveness and efficiency is very much needed. The development of the social character of elementary school-aged children has increased, from initially only socializing with family at home, then gradually getting to know the people around them.
\end{abstract}

Keywords: Character Education; Daring learning; Covid 19

\begin{abstract}
Abstrak
Penguatan pendidikan karakter memegang peran yang penting dalam membentuk karakter peserta didik. Bangsa yang besar adalah bangsa yang memiliki karakter sumberdaya manusia yang kuat berdampingan dengan kompetensi yang unggul. Pendidikan karakter adalah suatu proses penerapan nilai-nlai moral dan agama pada peserta didik melalui ilmu- ilmu pengetahuan, penerapan nilai-nilai tersebut baik terhadap diri sendiri, keluarga, sesama teman, terhadap pendidik dan lingkungan sekitar maupun Tuhan Yang Maha Esa. Kehadiran media di dalam dunia pendidikan, khususnya dalam rangka efektifitas dan efisiensi pengajaran sangat di perlukan. Perkembangan karakter sosial anak usia sekolah dasar sudah bertambah, dari yang awalnya hanya bersosial dengan keluarga di rumah, kemudian berangsur-angsur mengenal orang-orang disekitarnya.
\end{abstract}

Kata Kunci: Pendidikan Karakter; Pembelajaran Daring; Covid-19 


\section{A. Pendahuluan}

Pendidikan nasional berfungsi mengembangkan kemampuan dan membentuk watak serta peradaban bangsa yang bermartabat dalam rangka mencerdaskan kehidupan bangsa, bertujuan untuk berkembangnya potensi peserta didik agar menjadi manusia yang beriman dan bertaqwa kepada Tuhan Yang Maha Esa, berakhlak mulia, sehat, berilmu, cakap, kreatif, mandiri dan menjadi warga negara yang demokratis serta bertanggung jawab. (UndangUndang Sistem Pendidikan Nasional Pasal 3, 2003)

Menurut Marilin dan Ruly pembelajaran daring merupakan kegiatan pembelajaran yang dilakukan dengan cara memanfaatkan perangkat dan alat digital dan internet dengan tujuan menciptakan suasana belajar yang lenih menarik, kreatif dan mandiri. Pembelajaran daring tersebut dapat berupa penyampaian bahan ajar dan informasi, pemberian tugas dan interaksi secara dua arah antara guru dan murid selama proses pembelajaran berlangsung. Pada pembelajaran daring terdapat beberapa pilihan perangkat online yang dapat mendukung pembelajaran daring itu sendiri dan setiap perangkat pembelajaran daring memiliki sistem dan cara kerja yang berbeda diantaranya dapat berupa software/ aplikasi Google Classroom, Google Meeting, Zoom, Whatsapp, Youtube, Edmodo dan lain-lain.(Marilin \& Ruly, 2020)

Pendidikan karakter bertujuan agar peserta didik sebagai penerus bangsa mempunyai akhak dan moral yang baik, untuk menciptakan kehidupan berbangsa yang adil, aman dan makmur. Pendidikan karakter merupakan penciptaan lingkungan sekolah yang membantu siswa dalam perkembangan etika, tanggung jawab melalui model. Pendidikan karakter yang baik harus dilakukan dan dididik sedini mungkin agar masyarakat mampu menanamkan sifat-sifat dan perilaku yang baik sejak dini sehingga dapat menekan angka kriminal terlebih lagi di masa pandemic tenaga pendidik hanya mengandalkan teknologi digital untuk menunjang proses belajar dan mengajar kepada seluruh siswa di sekolah dasar.

Landasan pendidikan karakter disebut di dalam Alqur'an Q.S 31:17 “Hai anakku, dirikanlah sholat dan suruhlah manusia mengerjakan yang baik dan cegahlah mereka dari perbuatan yang mungkar dan bersabarlah terhadap apa yang menimpa kamu. Sesungguhnya yang demikian itu termasuk halhal yang diwajibkan oleh Allah".(Departemen Agama RI, 2000) Al-Qur'an menjelaskan dengan tegas agar manusia menyerukan dan menegakkan kebenaran dan menjauhkan perbuatan yang munkar. Pendidikan karakter yang diberikan seorang ayah kepada anaknya untuk selalu mengerjakan sholat, dan selalu bersabar. ${ }^{3}$

Pada masa pandemi Covid-19 ini Pemerintah mengeluarkan kebijakan tentang bagaimana pelaksanaan pembelajaran daring dan luring. Dalam kamus besar bahasa indonesia diartikan dalam jaringan, terhubung melalui jejaring komputer, internet, dan sebagainya.

Saat ini pembelajaran daring dinilai sebagai langkah tepat untuk dapat mencegah dan menekan penularan virus Covid-19, pun peserta didik tidak akan ketinggalan pelajaran sebagaimana yang telah direncanakan dalam kurikulum selama satu tahun ajaran akan tetapi sektor pendidikan khususnya pembelajaran di sekolah belum sepenuhnya berani dibuka oleh pemerintah. Hal ini dikarenakan anak usia sekolah adalah anak yang cendrung masih rentan dan senang akan berkumpul dengan temantemannya sehingga memungkinkan terjadinya penyebaran virus tersebut. Oleh karena itu pembelajaran yang dilakukan saat ini bersifat daring yang sifatnya jarak jauh. Sudah barang tentu menjadi tantangan tersendiri bagi guru dalam rangka capaian hasil belajar terutama dalam pendidikan karakter anak.

Dengan pembelajaran yang dilakukan baik di lingkungan sekolah mauppun diluar lingkungan sekolah dalam hal ini menggunakan pembelajaran daring yang sifatnya jarak jauh, memberikan tugas dan tanggungjawab ekstra serta tantangan bagi guru untuk mampu menciptakan lingkungan pembelajaran dalam upaya perkembangan etika, tanggungjawab dan karakter peserta didiktersebut.

Pada metode evaluasi dari pendidikan karakter salah satunya dengan observasi langsung oleh guru, yang mengamati sikap atau perubahan sikap baru yang muncul pada diri peserta didik. Belum lagi kendala yang dihadapi guru dalam penerapan pembelajaran daring misalnya penguasaan teknologi, kendala jaringan internet dan inovasi pengintegrasian pendidikan karakter pada pembelajran daring yang seolah baru booming ketika pandemi Covid-19 terjadi.

Karakter anak akan terbentuk apabila melakukan aktifitas secara berulang-ulang yang akan menjadi sebuah kebiasaan sehingga, membentuk suatu karakter pada anak tsersebut. Pembentukan karakter tidak dapat dilepaskan dari life skill. Life skill sangat berkaitan dengan kemahiran, mempraktekkan/ berlatih kemampuan, fasilitas, dan kebijaksanaan. Proses pengembangan keterampilan dimulai dari sesuatu yang tidak disadari dan tidak kompeten,kemudian menjadi sesuatu yang disadari dan kompeten.

Penanaman karakter dengan cara menanamkan nilai-nilai universal untuk mencapai kematangan karakter melalui penanaman cinta kasih dalam keluarga. Rasa rendah diri dapat menyebabkan 
seseorang melakukan kekerasan terhadap dirinya sendiri dan keluarga. Pendidikan sekarang ini masih melahirkan generasi yang ahli dalam pengetahuan sains dan teknologi, hal ini bukan merupakan suatu prestasi, karena pendidikan seharusnya menghasilkan generasi dengan kepribadian yang unggul dan sekaligus mengasai ilmu pengetahuan. Prinsip pendidikan karakter adalah segala sesuatu yang dilakukan guru, yang mampu mempengaruhi karakter peserta didik. Guru membantu membentuk watak peserta didik berdasarkan prinsip-prinsip pendidikan karakter.

Di masa pandemi baik guru/ pendidik dan orang tua hendaknya tidak boleh abai dalam hal pendidikan anak usia sekolah terutama pada pembetukan pendidikan karakter anak. Untuk mendukung keberhasilan pendidikan karakter, dampak positif dan negatif yang dibawa oleh kemajuan teknologi terlebih di era pandemi Covid-19 sudah semestinya disikapi dengan arif dan bijak. Dampak negatif pembelajaran daring yang mengharuskan siswa untuk bermain gadget yang terus menurus akan berakibat rusaknya moral, hendaknya diminimalisir sedemikian rupa dari orang tua dan guru agar siswa tidak dengan mudah mengakses konten yang bersifat negative untuk pertumbuhan anak. Sedangkan dampak posistif dikelola untuk meningkatkan kualitas pembelajaran dan menumbuhkan karakter siswa yang baik. Setiap lembaga pendidikan hendaknya sadar dan berupaya meningkatkan penggunaan dan pengelolaan pembelajaran daring dengan baik dan benar.

\section{B.TUJUAN PENULISAN}

Penulisan ini bertujuan memberikan wawasan dan paradigma kepada pembaca bahwa pembelajaran daring di masa pandemic ini sangat berpengaruh baik kepada orang tua, guru, terhadap penguatan pendidikan karakter anak terkhusus pada penumbuhan budi pekerti siswa, karena untuk menumbuhkan dan mengembangkan karakter positif siswa menjadi manusia yang gemar membaca, berwawasan luas, menumbuhkan kreatifitas, produktif, inovatif, dan demokratis sebagaimana cita-cita atau tujuan pendidikan nasional.

\section{C.METODE}

Penelitian ini bersifat kualitatif dengan teknik pengumpulan data dari berbagai referensi yang relevan dengan gejala yang diamati yaitu pada pendidikan karakter dalam pembelajaran daring untuk anak usia sekolah pendidikan dasar. Tujuannya adalah dapat dilihat permasalahan dan strategi pendidikan karakter terhadap penumbuhan budi pekerti siswa pada pembelajaran daring di masa pandemi covid- 19 saat ini. Menganalisis strategi pengintegrasian pendidikan karakter pada pembelajaran daring yang saat ini sebagai alternatif supaya proses bengajar mengajar dalam pemenuhan tuntutan kurikulum dapat tercapai dan terbentuk karakter yang unggul.

\section{HASIL DAN PEMBAHASAN}

Menurut Samani dan Hariyanto, pendidikan karakter adalah pendidikan yang mendukung perkembangan emosional siswa. Secara sederhana pendidikan karakter dapat diartikan sebagai hal-hal yang memiliki nilai positif yang dilakukan seorang pendidik dan berpengaruh pada karakter siswa ajarkan oleh guru/ pendidik tersebut. (Samani \& Hariyanto, 2013). Sehingga pendidikan karakter dapat diartikan sebagai sebagai tindakan yang mendidik yang dilakukan secara terus-menerus untuk membentuk karakter manusia sejak dini guna membenyuk generasi yang memiliki akhlak dan moral yang baik.

Empat hal yang mendasar mengapa sistem pendidikan di Indonesia perlu ditekankan pada pendidikan karakter yaitu: 1. Masih banyak keluarga di Indonesia yang tidak melakukan pendidikan karakter; 2. Peran sekolah tidak hanya membentuk manusia yang cerdas tapi juga manusia yang baik: 3 . Kecerdasaan seorang siswa akan bermakna jika juga disertai dengan perilaku yang baik: 4. Membentuk siswa yang berkarakter tangguh bukalah tugas tambahan seorang guru melainkan hal tersebut merupakan tugas yang sudah melekat pada seorang guru/ pendidik.(Akin, 1995)

Karakter merupakan perpaduan antara moral, etika dan akhlak..(Srigati, 2021) Dengan adanya perubahan pada metode belajar pada masa pandemic covid 19 yang tadinya pembelajaran biasa dilakukan dengan tatap muka digantikan dengan metode daring. Dengan metode tatap muka guru dapat dengan mudah mentransfer pengetahuan dan nilai-nilai karakter kepada siswa akan tetapi dengan beralih metode pembelajaran daring guru terkesan hanya menyelesaikan kurikulum dan kurang memunculkan pendidikan karakter yang seharusnya diberikan kepada siswa-siswa didiknya. Hal ini tentu harus mendapatkan perhatian penuh dari para pendidik dimana sampai saat ini masih belum diketahui berapa lama lagi pandemi ini akan masih terus berlangsung. Sehingga jangan sampai kita sebagai pendidik kehilangan momen berharga dalam membentuk karakter anak didik kita dari usia sekolah

Pembentukan karakter peserta didik harus melibatkan sinergitas ketiga komponen pendidikan antara lain pendidikan informal, formal dan non formal. Mengahadapi tantangan jaman yang saat ini memasuki era revolusi industri 4.0 yang sarat akan 
kemajuan teknologi digitalisasi, penanaman dan penguatan karakter bangsa sangat vital dan mendesak. Berkembangnya nilai-nilai individualistis, hedonis, materialistis dan sebagainya merupakan dampak buruk dari arus globalisasi dan revolusi industri 4.0 tersebut. Apabila hal ini dibiarkan maka dapat menimbulkan pengaruh negative bagi generasi penerus bangsa dan yang dapat berakibat pada kehidupan berbangsa yang tidak lagi mencerminkan nilai-nilai kepribadian bangsa.

Para guru/ pendidik harus mampu memodifikasi rencana pembelajaran sedemikian rupa agar metode yang digunakan dalam penyampaian materi ajar dan pendidikan karakter dapar berjalan seimbang. Bukan hanya sekedar pemberian tugas dan tugas saja akan tetapi metode pebelajaran yang dipakai harus tepat sasaran dan tidak menimbulkan rasa jenuh dan bosan terhadap belajar itu sendiri. Yang perlu diingat oleh setiap pendidik adalah peran guru dalam memberikan pendidikan dan pengajaran merupakan suatu hal yang utuh dan tidak dapat dipisahkan satu sama lain. Adapun peran guru sebagai pen-transfer nilai-nilai value dari pendidikan karakter tidak akan bisa digantikan oleh teknologi apapun sehingga peran guru sangatlah besar dalam pembentukan karakter generasi penerus bangsa.

Selain guru, orangtua juga memiliki peran yang sangat penting bagi pembentukan pendidikan karakter siswa mengingat pada masa pandemic saat ini siswa lebih banyak menghabiskan waktunya di rumah bahkan belajar pun saat ini lebih banyak dilakukan di rumah. Adapun yang harus dilakukan orangtua terhadap anak pada era yang serba digital terutama saat menggunakan metode pembelajaran daring yaitu selalu mendampingi anak dalam belajar termasuk dalam penggunaan gadget yang dipakai anak pada pembeajaran daring seperti handphone, laptop, tablet dan sebagainya.

Menurut Asmaul Chusna, penggunaan gadget yang berlebihan pada anak usia sekolah akan menimbulkan dampak buruk diantaranya dapat menurunkan daya konsentrasi dan meningkatkan ketergantungan pada anak. Selain itu anak yang sudah mengalami kecanduan gadget akan mengalami kesulitan dalam bersosialisasi dengan lingkungan sekitarnya yang pada akhirnya akan berdampak pada psikologis terutama mengalami krisis percaya diri dan mengalami gangguan pada perkembangan fisik anak. (Asmaul Chusna, 2017)

Pengunaan gadget yang berlebihan juga dapat pada kemampuan otak dalam mengontrol emosi, kontrol diri, tanggung jawab, pengambilan keputusan dan nilai-nilai moral lainnya. Hal ini terjadi dikarenakan anak yang kecanduan gadget seperti game online otaknya akan memproduksi hormon dopamine secara berlebihan yang mengakibatkan fungsi PFC atau Pre Frontal Cortex menjadi terganggu. Ketergantungan terhadap gadget pada anak-anak dapat menyebabkan mereka menganggap gadget itu segala-segalanya bagi mereka dan mereka akan merasa gelisah jika dipisahkan dengan gadget mereka. (Hastuti, 2012)

Dari beberapa dampak negative diatas yang ditimbulkan akibat penggunaan gadget yang berlebihan diantaranya kecanduan gadget dapat menurunkan daya konsentrasi dan fokus anak, kemamouan yntuk mengontrol emosi bahkan mengalami krisis percaya diri. Kecanduan gadget juga dapat mengakibatkan ganguan dalam berinteraksi social serta ketergantungan pada gadget itu sendiri. Oleh sebab itu diperlukan peran serta orangtua untuk selalu mendampingi dan mengkontrol anak dalam hal penggunaan gadget saat melalukan pembelajaran daring dimasa pandemi covid agar tidak menimbulkan efek-efek negative yang tidak diinginkan.

Secara garis besar beberapa komponen yang harus disiapkan dalam model pembelajaran daring sebagai infrastruktur pada pembelajaran daring antara lain seperti jaringan internet, strategi pembelajaran (berupa efek, gambar audio, video dan simulasi), menyediakan learning management system atau perangkat lunak (seperti zoom meeting, google meeting, google classroom, whatsapp, webex dll). Pada dasarnya keberhasilan proses pembelajaran daring memerlukan sinergi antara pemerintah, satuan pendidikan, guru, orang tua dan peserta didik itu sendiri serta lingkungan yang mendukung proses pembelajaran daring tersebut. (Eka Santika, 2020)

Pembelajaran daring dilakukan melalui grub whattsap, google clasroom dll. Lebih lanjut dirjen guru dan tenaga kependidikan Kementrian Pendidikan dan Kebudayaan dalam guru pembelajaran petunjuk teknis peningkatan program peningkata kompetensi guru pembelajar moda dalam jaringan tahun 2016 menjelaskan Pendekatan pembelajaran pada Guru Pembelajar moda daring memiliki karakteristik sebagai berikut: 1. Menuntut pembelajar untuk membangun dan menciptakan pengetahuan secara mandiri (constructivisme); 2. Pembelajar akan berkolaborasi dengan pembelajar lain dalam membangun pengetahuannya dan memecahkan masalah secara bersama-sama (social constructivisme); 3. Membentuk suatu komunitas pembelajar (community of learners) yang inklusif; 4. Memanfaatkan media laman website yang bisa diakses melalui internet, pembelajaran berbasis komputer, kelas virtual, dan atau kelas digital; 5. Interaktivitas, kemandirian, aksesibilitas, dan pengayaan ${ }^{12}$ 
Kelebihan pembelajaran daring diantaranya adalah, 1. Pembelajaran tidak memerlukan ruang kelas, karena proses pembelajaran berlangsung dari rumah atau jarak jauh. Siswa di tempat atau lingkungan masing-masing yang dapat menciptakan suasana belajar dengan fasilitas internet yanga ada.,

2. Guru tidak perlu tatap muka secara langsung di depan kelas, karena yang digunakan adalah fasilitas komputer yang dihubungkan dengan internet. 3 . Tidak terbatas waktu maksudnya adalah pembelajaran bisa dilakukan kapanpun, dimanapun sesuai dengan kesepakatan selama lingkungan dan fasilitas mendukung untuk terlaksananya proses pembelajaran mode daring tersebut. Oleh karena itu mode pembelajaran daring ini bisa dikatakan lebih efisien dan efektif apabila suprastruktur dan infra struktur tersedia dengan baik. Suprastruktur dapat diartikan penulis sebagai kebijakan yang mengarah pada pelaksanaan pembelajaran daring tersebut termasuk pemahaman dan kesiapan peserta didik dan guru dalam pelaksanaan pembelajaran daring.

Adapun implementasi penguatan pendidikan karakter dapat dilakukan dengan tiga pendekatan utama yaitu pendekatan berbasis kelas, pendekatan berbasis budaya sekolah dan pendekatan berbasis masyarakat. Implementasi PPK berbasis kelas dibagi menjadi pengintergrasian PPK dalam kurikulum, manajemen kelas, penggunaan metode pembelajran, melalui pembelajaran tematis, gerakan literasi dan layanan bimbingan konseling. (Konsep Dan Pedoman Penguatan Pendidikan Karakter, 2016)

Berbicara pendidikan karakter maka akan erat kaitannya dengan budi pekerti, hal ini dikarenakan karaktek yang baik ditandai dengan sikap budi pekerti yang baik. Konsep dasar pendidikan karakter tertuang dalam Permendikbud No 23 tentang Penumbuhan Budi Pekerti tahun 2015. Penumbuhan Budi Pekerti (PBP) bertujuan:1.Menjadikan sekolah sebagai taman belajar yang menyenangkan bagi siswa, guru, dan tenaga kependidikan; 2. Menumbuh kembangkan kebiasaan yang baik sebagai bentuk pendidikan karakter sejak di keluarga, sekolah dan masyarakat; 3. Menjadikan pendidikan sebagai gerakan yang melibatkan pemerintah, pemerintah daerah, masyarakat dan keluarga, dan/ atau 4.Menumbuh kembangkan lingkungan dan budaya belajar yang serasi antara keluarga, sekolah, dan masyarakat. Pemberian contoh yang baik kepada siswa akan menanmkan nilai-nilai moral dan spiritual misalanya membiasakan membuka dan menutup pelajaran dengan berdoa sesuai dengan agama dan kepercayaan masing-masing, membiasakan siswa untuk melakukan ibadah bersama sesuai agama dan kepercayaannya baik dilakukan di sekolah maupun bersama masyarakat, dan lain-lain. Selain itu melakukan pembiasaan-pembiasaan yang baik yang dapat di lakukan di sekolah atau dicontohkan oleh guru misalnya memberi salam, senyum, sapaan kepada setiap orang, pembiasaan mengucapkan kata maaf, permisi dan terimakasih kepada oranglain ataupun pembiasaan murid mengucapakan salam hormat kepada guru sebelum pelajaran dimulai pembelajaran tersebut dilakukan secara daring ataupun tatap muka. Meskipun hal-hal diatas terkesan sederhana akan tetapi jika sejak dini ataaupun usia sekolah anak-anak sudah dibiasakan untuk memiliki budi pekerti yang baik maka saat dewasa ia akan terbiasa dan akan terbentuk karakter yang baik pula.

\section{PENUTUP}

Pada masa pandemi covid 19 saat ini, pendidikan karakter tidak boleh diabaikan dalam proses pembelajaran. Hal ini dikarenakan pendidikan yang baik bukanlah sebatas memberi dan menerima bahan ajar dari guru kepada siswa, namun dibalik itu ada sikap positif yang tumbuh dan terbentuk yaitu karakter yang baik dan santun yang kemudian menjadi karakter yang melekat pada peserta didik. Dalam membentuk karakter generasi bangsa diperlukan peran serta aktif guru , orangtua, dan masyaraka yang saling bahu membahu membentuk karakter generasi penerus bangsa. 


\section{DAFTAR PUSTAKA}

Akin. (1995). Character Education in America's Schoo. Innerchoice Publishing.

Asmaul Chusna, P. (2017). Pengaruh Gadget Pada Perkembangan Karakter Anak. Dinamika Penelitian, STIT AlMuslibun, Vol.17 No.2.

Departemen Agama RI. (2000). Al-Quran dan Terjemahannya.

Eka Santika, W. (2020). Pendidikan Karakter Pada Pembelajaran Daring. IVCEJ. Universitas Dwijendra Denpasar.

Hastuti, H. (2012). Psikolog Perkembangan Anak. Tugu Publisher.

Konsep dan Pedoman Penguatan Pendidikan Karakter, Tingkat Sekolah Dasar dan Sekolah Menengah Pertama. (2016).

Kementerian Pendidikan dan Kebudayaan RI.

Marilin, K., \& Ruly, N. S. (2020). Model Pelaksanaan Pembelajaran Daring Pada Masa Pandemi Covid 19 di Provinsi Lampung. Jurnal Idaarah, IV, No: 2, 200-209.

Samani, M., \& Hariyanto, H. (2013). Konsep dan Model Pendidikan Karakter. PT. Remaja Rosdakarya.

Srigati, D. (n.d.). Membentuk Karakter Siswa di Masa Pandemi Covid 19.

Srigati, D. (2021). Membentuk Karakter Siswa di Masa Pandemi Covid-19 [Preprint]. Open Science Framework. https://doi.org/10.31219/osf.io/vxc3q

Undang-Undang Sistem Pendidikan Nasional Pasal 3. (2003). 